\section{Darwin, Lyell and gradualism}

SIR-In an elegant essay, Rhodes' convincingly demonstrated that Darwin was not a strict gradualist - that he was, in fact, a pluralist and his views overlapped what over the past decade or so has been hailed as a new theory, "punctuated equilibria". According to Rhodes, Darwin recognized a component of stasis, a tenet of punctuated equilibria, and repudiated the gradualistic aspect of evenness in transformation but "...whether it was 'slow' depends on our definition of speed"; slowness is not synonymous with gradualism. Darwin, Rhodes correctly points out, clearly appreciated the significance of local, periodic speciation and its representation in the fossil record. Although rapidity of speciation is associated with punctuation, Rhodes argues that this rapidity might well be encompassed within the "gradualism" of Darwin; whether "gradual" or "rapid" becomes a matter of definition.

Recently, Dawkins ${ }^{2}$, in his review of a book Time Frames: The Rethinking of Darwinian Evolution and the Theory of Punctuated Equilibria ${ }^{3}$ by one of the originators of the theory, Niles Eldredge, substantiates many of the claims of Rhodes. Although the fervent punctuationists have stressed the revolutionary and anti-darwinian aspects of the concept, Dawkins states that "it lies firmly within the neo-darwinian synthesis". Darwin emphasized the term "gradual" in his campaign against creationism; in such a context, explains Dawkins, gradualism is practically synonymous with evolution itself. "The punctuationists deluded themselves that they were saying something revolutionary. And it was all due to a simple verbal misunderstanding: a confusion of two senses of the word 'gradual'."

In a very recent defence of "lyellian uniformitarianism", $\mathrm{I}^{4}$ have, by referring to Lyell's original works, demonstrated that he certainly appreciated episodicity, both past and present, and clearly incorporated that concept in his use of "gradual". In a parallel situation (and with some overlap) to Darwin's combat with creationists in the palaeontological and biological realm, Lyell was waging an intense philosophical battle against the catastrophists, a still very vociferous and influential group in the 1830 s when his early editions were written. In comparison with this antagonistic philosophy, which emphasized truly cataclysmic events beyond our present knowledge, Lyell's uniformitarianism seemed gradualistic, and was - relatively speaking; he used "gradual" in a broader sense than most have realized. One quotation from the first edition of his Principles of Geology describing the episodic uplift of a faultbounded mountain range serves as a rep- resentative statement of his concept of "gradual": "We know that one earthquake may raise the coast of Chili for a hundred miles to the average height of about five feet. A repetition of two thousand shocks of equal violence might produce a mountain chain one hundred miles long and ten thousand feet high. Now, should only one of these convulsions happen in a century, it would be consistent with the order of events experienced by the Chilians from the earliest times"."

In another recent review, Cloud ${ }^{6}$ criticized authors who labelled Lyell a gradualist, advising them to review original sources. Cloud has suggested (personal communication), correctly I feel, that Lyell's sense of gradual and uniform was with regard to the "long average". Although he frequently used the word uniformity, it seems clear from content that what he had in mind was far from simple gradualism.

I think that both Darwin and Lyell have been rather seriously misjudged with regard to their use of "gradual". For more than a century, it seems we have cast aspersions on their gradualism without appreciating the context of their times and, apparently, frequently without carefully consulting the original sources.

Department of Geology,

DONALD H. Zenger

Pomona College,

Claremont, California 91711, USA

1. Rhodes, F.H.T. Nature 305, 269-272 (1983)

2. Dawkins, R. Nature 316, 683-684 (1985).

3. Eldredge, N. Time Frames: The Rethinking of Darwinian

Evolution and the Theory of Punctuated Equilibria (Simon and Schuster, New York, 1985)

4. Zenger, D.H. J. Geol. Ed. 34, 10-13 (1986)

5. Lyell, C. Principles of Geology Vol. 1 (John Murray. London, 1830)

6. Cloud, P. Bull. Am. Ass. Petr. Geol. 69, 138-139 (1985)

\section{Problems of Africa}

SIR-I have often wished that your Opinion and News columns showed more awareness of the Third World's worsening problems; but if your editorial "Who will pity Africa?" (Nature 321, 548; 1986) is the best you can do, it might be better to remain silent. In one column of pontification you reveal a remarkable ignorance of Africa's history and economy, and even of recent events in the continent.

You say that Uganda, once a kind of paradise, "has now settled for inter-tribal violence and the chaos that follows". Apart from the fact that Britain fostered tribal rivalries in colonial days by recognizing the Kabaka of Buganda as ruler, and then backed two disastrous leaders (Obote, Amin and Obote again) who deepened these divisions, you seem to have missed the news earlier this year that Uganda now has a widely popular president (Musevini) who offers real hope of reconciliation.

Your reference to Nigeria having "squandered" its oil wealth is also somewhat misplaced, in view of the fact that Britain's oil boom appears to have financed nothing more tangible than tax cuts for the better-off. Would you call this a good example?

Worse than all of this, however, is your failure to comment on the external factors, particularly falling commodity prices, that lie at the heart of Africa's crisis. For example, Tanzania spends 60 per cent of its external earnings on oil, and while 1 tonne of tea paid for 60 barrels of oil in 1972 , by 1980 it bought only $4 \frac{1}{2}$ barrels. In the same period, the amount of coffee needed to pay for a lorry rose from 5 to 28 tonnes. This is the "free market" over which Africa has no control.

There has been no shortage of "good ideas" on what to do next, but Western governments have found most of them deeply unpalatable. Instead of joining $\mathrm{Mr}$ Schulz in lecturing Africans on their improvidence, you could start by asking why Britain and the United States have so far failed to contribute to the special programme for sub-Saharan Africa set up by the International Fund for Agricultural Development.

Michael Spencer

\section{Bayham Road,}

Sevenoaks,

Kent TN13 $3 X E, U K$

\section{Condoms in Japan}

SIR-Legalization of the contraceptive pill seems to be regarded as an entirely positive development. The cautiousness of the Japanese authorities has, however, contributed greatly to the wide popularity of the condom, which is more frequently used than any other form of contraception.

The low incidence of acquired immune deficiency syndrome (AIDS) in Japan and the relaxed attitude towards the possible spread of the disease among the general population, as well as the low incidence of infertility caused by salpingitis, may be explained in part by the widespread use of the condom.

Rather than Japan copying Western habits of contraception, it would be better for those in the West to attempt to understand (and possibly copy) the cultural patterns that make this simple contraceptive acceptable to Japanese men and women rather than being considered unnatural and unwelcome.

BO WARMING

Sperm-Help Foundation,

Bjelkes Alle 46,

DK-2200 Copenhagen $N$,

Denmark

1. Nature 317. 760)(1985)

2. Coleman. S. Family Planning in Japanese Society (Princeton University Press, 1983)

Nature 318. 306 (1985) 